\title{
"After Months of It, You Just Want to Punch Someone in the Face": Stay-at-Home Fathers and Masculine Identities
}

\author{
Catherine Richards Solomon, $\mathrm{PhD}$ \\ Quinnipiac University \\ * Please address correspondence to Dr. Catherine Richards Solomon, Department \\ of Sociology, Mail Drop CL-AC1, Quinnipiac University, 275 Mount Carmel \\ Avenue, Hamden CT 06518. Email: catherine.solomon@quinnipiac.edu.
}

\begin{abstract}
A new definition of fatherhood has emerged that prescribes more hands-on involvement from fathers, particularly with small children. In addition to this new approach to fathering, there is a small but growing number of stay-at-home fathers. Scholars know little about stay-at-home fathers in the U.S. as the majority of research has been conducted in other countries. As being a stay-at-home father is a deviation from an important tenant of hegemonic masculinity, one of breadwinning, what are the gender-related challenges these men face because of their roles? How do stay-at-home fathers respond to these challenges? I explore these questions in my study through in-depth interviews with stay-at-home fathers from across the United States. My study shows that a new definition of masculinity is emerging to support such men's engagement in family life.
\end{abstract}

Keywords: stay-at-home fathers; gender; family roles, masculinity

"I bundle up Moira and Kate And take them to ballet which is great And I sit and read a book in the hall And mothers do not talk to me at all. They sit down at their end and I at mine And they glance my way from time to time And those little glances really hurt."

- "The Only Living House Dad in Eau Claire" by Garrison Keillor

As depicted in this song by Garrison Keillor, stay-at-home fathers are relatively uncommon despite an increased presence in mainstream TV shows like NBC's Parenthood or ABC's Up All Night and in TV commercials. Current estimates from the U.S. Census show stay-at-home fathers to number around 190,000 (U.S. Census, 2013). This is a substantial increase from 2002 when such 
dads were close to 100,000 (Fields, 2003). The rise in their numbers is perhaps a reflection of the changing expectations of fathers.

Fathers, like mothers, have experienced shifts in their role in the last 40 years. Whereas economic provision and breadwinning has comprised a significant part of fathering in the past, current models of fathering encourage more hands-on involvement (Lamb, 2000; Pleck \& Pleck, 1997). Such "involved fathering" entails taking responsibility for daily caregiving activities and being engaged and attentive to children's needs. Fathers are more likely to be involved with and responsible for childcare if their wives are employed outside the home (Jacobs \& Kelley, 2006) and if the fathers themselves are well-educated and middle- to upper class (Marks \& Palkovitz, 2004). This expectation of increased involvement creates tension. More men are reporting conflict between work and family, wishing to spend fewer hours at work and more time at home (Aumann, Galinsky, $\&$ Matos, 2011). Despite this desire, many fathers do not care for their children an equal amount of time as their wives (Shows \& Gerstel, 2009) or reduce their paid work hours (Aumann, Galinsky, \& Matos, 2011). This lack of involvement could stem from men's continued identification with the family breadwinner ideal that supports traditional masculinity (Aumann, Galinsky, \& Matos, 2011). Investing many hours in childcare (and therefore not in paid work) contradicts the traditional ideal of fatherhood and tenents of traditional masculinity. Stay-at-home fathers represent one type of involved father, but research about their experiences is scarce, particularly in the United States. I address the following questions in my exploratory study of 32 stay-at-home fathers from locations across the United States: What are the gender-related challenges these men face because of their family behaviors? How do stay-at-home fathers respond to these challenges? In my study, I demonstrate that stay-at-home fathers challenge hegemonic masculinity when faced with resistance to their caregiving and, in doing so, create a new masculine ideal: "evolved masculinity."

\section{Research about Stay-at-Home Fathers}

Much research about stay-at-home fathers has been conducted in other countries (Doucet, 2004, 2006, 2009; Merla, 2008; Wall et. al., 2007). Research on stay-at-home fathers in the United States has examined the psychological aspects of this role (Rochlen, McKelley, Suizzo, \& Scaringi, 2008; Rochlen, Suizzo, McKelley, \& Scaringi, 2008; Rochlen, McKelley, \& Whittaker, 2010), with little attention being given to the sociological aspects (Chesley, 2011). It appears that there are two major factors that facilitate men's transition into the roles of stay-at-home parents. One, families believe one parent should be the fulltime primary caregiver for their children (Chesley, 2011; Doucet, 2006; Solomon, 2014; Wall et. al., 2007). Two, men experience either personal job transitions or changes with their wives' jobs (Chesley, 2011; Solomon, 2014). Within the context of a society that expects more hands-on involvement, these two factors push men toward home.

Once staying at home, some men experience disapproval from others for not working for pay (Doucet, 2006; Doucet \& Merla, 2007) as well as exclusion from playgroups (Merla, 2008). Most fathers acutely feel the loss of their 
breadwinner role (Chesley, 2011; Doucet, 2009; Wall et. al., 2007). To compensate for this loss, many stay-at-home fathers in previous studies emphasize their work on traditional masculine activities around their houses and in the community or by working part-time for pay (Chesley, 2011; Doucet, 2004, 2006). In her article about stay-at-home fathers and masculinity, Doucet (2004) argues "the long shadow of masculinity hangs over them while also pointing to hints of resistance" (pg. 277) to hegemonic masculinity. In addition, she wrote men in her sample are "adamant about distinguishing themselves as men ... as masculine" and they find ways of "reinforcing their masculinity" to reaffirm their identities (pg. 292, italics in original). However, in my exploratory study with stay-at-home fathers from across in the United States, I found different experiences in regards to men's experiences with challenges to traditional masculinity. Unlike men in previous work, the fathers in my sample are more resistant to ideals of traditional masculinity and do not seek out ways to compensate for their non-traditional caregiving duties.

Research findings from countries offering more policy support for father involvement than the U.S. may not be easily translatable to men's experiences here (Wisensale, 2001). One U.S.-based sociological study relied on a small geographically specific sample of 13 White current stay-at-home fathers from southeastern Wisconsin (Chesley, 2011). Chesley found that husbands and wives, through their interaction, contest or support traditional gender ideologies. Whereas Chelsey's (2011) study focused on couples' interactions within families, my work explores the interplay between traditional masculine ideology and stayat-home fathers' experiences.

Kramer, Kelly and McCulloch conducted a study about the prevalence and characteristics of stay-at-home fathers using Current Population Study data (2010). They defined stay-at-home fathers as men who were not part of the labor force and who earned no income in the last 12 months. Using this stringent definition, they found that men who identify as stay-at-home fathers are predominantly married, heterosexual, college-educated (or beyond) middle-class men, with an average age of 44 , married to women with education levels that exceed their own. Thus, stay-at-home fathers, in general, are a privileged group of men in the U.S. These previous studies provide a starting point for an in-depth sociological examination of stay-at-home fathers' experiences of and responses to challenges to masculinity.

As mentioned above, men's paid employment is a taken-for-granted component of family life and of traditional masculinity. Beginning with industrialization, men's breadwinning ability has underscored their performance of masculinity (Connell, 2005; Ferree, 1991). By being breadwinners, men affirm their sense of masculinity, in addition to maintaining economic advantage over women. Yet at the same time, a definition of masculinity that encompasses different activities has emerged - one Cooper called "new masculinity" (2002, p. 5). This definition allows for simultaneous involvement in childcare and paid work. As Connell (1987) wrote, hegemonic masculinity can exist in multiple forms and is not a fixed characteristic. Indeed, Connell (1987) argued that scholars should "focus on the processes and relationships through which men 
conduct gendered lives" (p. 71, italics added) when studying masculinity. As being a primary caregiver for children "is not a fit occupation for men" (Connell, 1987, p. 106) studying stay-at-home fathers can illuminate the multiple ways in which men perform gendered lives and, perhaps, demonstrate that a new way of practicing masculinity is emerging. What are the gender-related challenges that stay-at-home fathers experience and how do they respond to these challenges? I explore these questions in my study.

\section{Methods}

To address my research questions, I conducted in-depth semi-structured interviews with 32 stay-at-home fathers. Previous studies have defined stay-athome fathers as: men who were not working for pay (Doucet \& Merla, 2008), "men who are, or were, caring for at least one child under 12 for a minimum of six months while their wives worked fulltime and earned at least 80 percent of the family income" (Chesley, 2011, p. 647), men who are not in the labor force or who did earn any income in the last year, and whose wives earn all family income (Kramer, Kelly, \& McCulloch, 2010), men who defined themselves as "primary caregivers" whether they were employed or not (Latshaw, 2011, p. 131) or men who were laid off or underemployed but looking for work in their field (Lane, 2009). I defined stay-at-home fathers as men who were primary caregivers for their children while their wives worked full-time for pay and who worked for pay no more than 10 hours a week. The final sample consisted of only four men who did any work for pay. These four men worked, on average, much fewer than 10 hours a week: two as photographers, one as a men's group leader and one as a fiction writer. I recognize that my definition of stay-at-home fathering may be narrow and may exclude men who consider themselves stay-at-home fathers (Lane, 2009; Latshaw, 2011). However, I wanted my sample of men to be one in which all the men considered their only "jobs" to be caring for their families.

I recruited my sample through a variety of means. I used snowball sampling, an announcement on a stay-at-home fathers group's website, announcements to professional listservs, and posters put in local places I thought stay-at-home fathers would be likely to go (e.g., library, coffee shops). Interviews ranged from one hour to two-and-a-half hours. I asked participants about a variety of topics, including the decision process in becoming stay-at-home fathers, their daily activities, their feelings about being stay-at-home fathers, and their expectations for the future. I interviewed nine men in person and 23 men over Skype. A professional transcriptionist transcribed the interviews.

\section{Sample Characteristics}

All men in my sample were white, married, and heterosexual. Participants lived in states across the United States. The average length of time staying at home was 5 years. Length of time staying at home ranged from 14 years $(9 \%$ of the sample) to one year ( $31 \%$ of the sample). $28 \%$ had been staying at home for between 5 and 10 years and for $31 \%$, between 2 and 4 years. The mean age of fathers was 40 years old with a range from 27 to 51 years old. Children's ages ranged from five months to 17 years old. All participants except one had college 
degrees and most were married to wives with some college education. Many of the husbands and wives had post-graduate education. My sample, although not nationally representative, is similar to national Current Population Study data on stay-at-home fathers (Kramer, Kelly, \& McCulloch, 2010) and is a privileged group of fathers in terms of race-ethnicity, class, education, and income.

\section{Data Analysis}

I followed Bogdan and Biklen's approach to qualitative data analysis (1998). This approach entails reiterative readings of the interview transcripts, looking for ideas and concepts that frequently emerge from the data. In addition, I routinely immersed myself in the literature to inform my analysis. This process allows for (re)conceptualizing of key ideas and topics. These topics and ideas represent important "codes" that illustrate these men's experiences staying at home and of masculine identities (Bogdan \& Biklen, 1998). Codes are then grouped into larger themes that illustrate different aspects of fathers' experiences as stay-at-home fathers, and, for the purpose of this paper, masculine identities. In this paper, quotes are representative of other participants' comments unless otherwise noted. I use pseudonyms for each respondent and changed potentially identifying information.

\section{Limitations of the Sample}

This sample is limited by the lack of racial-ethnic, sexual orientation, and class diversity. None of these men had to contend with issues of discrimination in terms of these social locations. Thus, they dealt with challenges to their masculine identities against a backdrop of privilege. Such status means they had access to social privileges and other resources that allow them flexibility in how they responded to challenges and how they enacted masculinity.

\section{Results}

Unlike prior research, men in my study mostly experienced positive reinforcement for being stay-at-home fathers (Solomon, 2014). Family members, friends, and others in their communities were by and large supportive of their familial arrangements. This signals that perhaps societal ideals about fatherhood have shifted away from the breadwinner model (Solomon, 2014), at least among privileged men. Yet, reflecting earlier findings (Chesley, 2011; Doucet, 2004, 2006), my participants also described poignant instances in which they experienced challenges to their masculinity. What is different about the men in my study is that while they experienced some emasculation, most did not attempt to enact masculinity through traditional masculine household or community activities. This result is different from prior research perhaps because participants in my study received more support from their networks than men in previous studies. Men in my sample enjoyed privileges that accompany being middle- and upper class. As we know from prior research (Cooper, 2000; Risman, 1998), individuals in the upper classes tend to espouse more egalitarian views about caregiving than individuals in other classes. Thus, these men were in communities in which being stay-at-home fathers may be seen in a more favorable light than 
men in lower-class or poor communities. Before I describe how men in my sample responded, let me first describe the challenges.

\section{Challenges to Masculinity}

Challenges to masculinity came from external sources (such as friends, family members, or strangers), internal pressures, or both. For example, Chad mentioned how his friends routinely teased him about being a stay-at-home father. He told me:

A lot of other guys, you hear the Mr. Mom comments from them. The baby would start crying and someone would be like, "Well, why don't you just breast feed her?" Just little things like that. And it's really funny, at first; it really is, like just guys being guys, right? And I don't mind guys being guys. But after months of it you just want to punch someone in the face.

Eric's performance of masculinity was challenged because of the lack of fit between his former status as a Marine (a status closely aligned with traditional masculinity) and his current status as a stay-at-home father. He said, "I went from eight years of infantry war, ready to murder people, to staying home with a newborn ... If anyone knows that I'm a Marine then there's a whole set of expectations. And a whole set of pressures and ideals that I have to match up for them." Gender theorists argue that when men do not "do gender" according to traditional gender ideologies, others police their behavior and give out sanctions for behavior seen as "deviant" (Connell \& Messerschmidt, 2005; Kerfoot \& Knight, 1998; Lorber, 1994; West \& Zimmerman, 1987). Thus, these participants were experiencing gender policing because their behavior as fathers was at odds with the behavioral prescriptions of traditional masculinity.

The incongruence between traditional masculinity and these men's familial behaviors meant their former accomplishments that made them successful "men": military engagement, academic accomplishments, high salaries, athletic capabilities, or occupations, now seemed meaningless. Eric shared,

My own self-esteem was based off of my accomplishments. I served in the Marine Corps, I graduated top of my class, I went to the [name of military school], the hardest school that I could volunteer to do. So I have a lot of pride in doing that. I served after 9/11 overseas, I got out and I was a firefighter, I crawled into a burning building, I put a house fire out, all of these things for me made me who I was. And when I started staying home and watching my kids, all of a sudden the time and distance between these accomplishments I had stretched out and it became less and less a point of legitimacy for me to prove myself to other people.

Craig referred to his academic accomplishments as a source of pride, but, like Eric, these accomplishments seem minimized after staying at home with his three children, "I think a feeling of emasculation does creep in there at times. I try to be alpha male about it as much as possible, and I think I do a pretty good job of it, but there's times where I'm like, gosh, here I was a magna graduate, I was going 
to go off to [Prestigious University] to get my Ph.D., all this stuff and then [I became a stay-at-home dad]." Similarly, Chad felt less like a "man" because he no longer did masculine activities like playing sports or working for pay. $\mathrm{He}$ shared,

It felt emasculating . . . All through high school - I was a three-sport athlete. I was an academic all-American. I was desired by a lot of people. My father grew up as a breadwinner for the family and I look up to my father a lot. I wanted to be a breadwinner growing up. And I wasn't. When I was like working hard, making money, it wasn't even a lot of money, but I was supporting us, and I felt good. It felt good every day. I felt like a man when I was doing that (emphasis added).

Chad's emasculation was strong enough that is negatively affected his sex life with his wife. He felt less interested in sexual activity and less sexually desirable because he was not "manly" enough. He said that the feeling of being a man when he was working for pay,

would transfer itself to other parts of our life. But [staying at home]'s been a challenge sometimes when I don't feel that way \{like a man $\}$ and I don't initiate sex ... it's mostly a confidence thing, on my part. I'd say that's what goes with being a breadwinner. A man, at least from my perspective, me, I gain so much confidence from that. And that's what I was trying to get to when I felt like desired, like I said before. And there are lots of times when I don't feel desired at all, as a person, and as a man.

Because Chad was not a breadwinner and was not admired any longer for his masculine accomplishments, his identity as a "man" suffered and there was a ripple effect to other parts of his life. Being "men" was easier when participants were working for pay because it supports how "real" men behave - and thus, the norms of traditional masculinity. Thus, these men sometimes felt tenuous about their "manliness." As these are white heterosexual middle class men, they were not used to having their statuses questioned because they occupy a position of privilege in society. Now, however, because their familial behavior is viewed as deviant for men, they experienced some criticism. Therefore, even though their class status likely provided a buffering effect in terms of criticism related to their masculine identities (as I described above), there were still feelings of emasculation.

\section{Responses to Challenges}

Some men adopted a neutral stance, whereas other men challenged individuals who questioned their behaviors. In addition, most men accepted their non-traditional enactment of fatherhood and took pride in how they provided for their families and the skills they had developed. 


\section{"It Doesn't Bother Me"}

Some men said that it didn't bother them or they found humor in their marginality. Kyle was an example of the latter strategy. He said about the local mothers group's website in his town,

Like here I am hanging out in the [Town] Moms [site]. [This example is] a small thing, it doesn't really matter, but I think it is sort of indicative of just sort of a bigger issue, that [being a stay-at-home dad]'s not quite asit's accepted, it's just I don't think it's unconsciously as normal and as accepted as a mom staying home is. That's all. So my brother always jokes that I was hanging out in the [Town] Moms (and Kyle) site, it's like you kinda have to joke about it.

Joel said something similar about children's classes,

Last year, we had something called a "Mommy and Me" class. And I defy any man to sit in a Mommy and Me class where the teachers have been there for 400 years, and everything is geared towards mommies. And you kind of feel like, I'm not saying, gear it towards me, even though I was the only guy there for nine months with these two kids, but you learn a lot about yourself and you have to have a pretty healthy sense of humor about it.

Other men relied on the image of a lone man who doesn't need social interaction and who doesn't care what others think. For example, Corey said, "But I will run into conversations where I bring up I'm a stay-at-home father and get the same glassy look. And it's annoying, but I just don't internalize it all that much. I just don't care." Similarly, Timothy said, "There were times when I felt like I was viewed a little suspiciously... like I wasn't doing the right thing. It was frustrating at the time, but on the other hand I've never tried to pay too much attention to what other people thought ... It's not something that I lost sleep over or anything like that." These men were quick to point out that they were not bothered by this social exclusion, as such emotion would contradict hegemonic masculinity's doctrine of stoicism (Connell, 1987; 2005). Thus, they relied on prescriptions of stoicism, perhaps as a coping mechanism for the challenges that they experienced in the community. Alternatively, this stoic response also demonstrates successful gender socialization into traditional masculinity and doing gender appropriately (Connell, 1987, 2005; West \& Zimmerman, 1987). By responding with stoicism, they affirm their masculinity.

\section{Challenging Others}

Some men challenged others' negative comments about their masculinity. Fred was one such man. He was a devout Christian and others in his community used religious beliefs to question his status. He shared,

[They tell me] a man who doesn't provide for his own family is worse than a nonbeliever. But I always tell them, I said, "So who is providing for the family more? Somebody who brings home the money and is not very involved in the family, or the person who cooks, cleans, wipes snotty 
noses, wipes the bottoms, does everything around the house?" And they usually don't have an answer. And I also generally say, "I'm providing. I found a wife who makes more money than I did." It's not much different than having a boss who pays you money.

Fred's comment about his wife being similar to a "boss who pays" him money hints to a power differential in his marriage and that Fred sees his work as for his wife, who is his boss. He is doing work for his wife, who is in charge of the family (by being the boss). Thus, whereas hegemonic masculinity puts men in a dominant position in their families, Fred puts himself in a subordinate position, which illustrates how men's enactment of masculinity may rely less and less on a position of dominance in the family.

Eric also actively resisted pressure from others to put his children in daycare and find paid work, so much so that he cut off contact with his family. He said, "Being the Marine Infantry guy I was, I didn't take it from them. I basically told them off. I said, "Look, I'm watching my kid. This is how we do it." They were like, "Well, why don't you get a babysitter? This isn't what you should be doing. A man needs to get a job!" And fast forward, I [still] have no contact with my side of the family." Unlike previous research (Doucet, 2004; 2006), these men's overt resistance perhaps demonstrates an evolution of ideals of masculine behaviors toward, or beyond, new masculinity with its acceptance of involvement in caregiving. Aumann, Galinsky, and Matos' (2011) research on men's increased work/family conflict supports that idea as it appears an increasing number of men are committed to being involved fathers.

\section{Acceptance of Non-traditional Status}

Most participants simply accepted that others viewed them as nontraditional. Many men said they were comfortable with this view and with the way they performed masculinity. For example, Craig shared,

I try not to get caught up in the vortex of cultural and societal expectations, which is not an easy thing to do. And just go with what is and try to keep a positive attitude. [And realize that] some women like alpha males. But alpha male doesn't necessarily mean that the husband isn't going to be a stay-at-home dad. It's his attitude that he brings with it, and that makes it tolerable ... [and] I don't define myself by my career, I'll put it that way. So I don't need a career to validate anything [about] myself.

Some men saw themselves as deviating from traditional masculine behavior throughout their lives. Thus, reconciling their caring behaviors (as stay-at-home fathers) with traditional masculine behaviors was not necessary. Theo shared this, I've always resisted some of those stereotypes. And I think part of it was I feel I've always been a feminist, I've always supported equality. I feel like I was raised by a very strong mother. The idea of gender, I just wanted to leave out of a lot of the way I thought about things and part of it was because being male, I didn't like being pinned to those stereotypes. 
Actually that's what I disliked most about the other males that I knew. So I didn't want to be associated with that. So I tried to make it that it's not a male thing, it's well that guy is a jerk. You know? Those are the jerks and then there's the nonjerks, as opposed to there's the men and the women. And I didn't want to be associated with the violence or the aggression or any of that stuff. So I think just growing up I always tried to like not focus on gender, which actually is probably focusing on gender.

Although most of the men in my sample did not speak about a feminist background and did not attribute their stay-at-home status to feminist ideals, Theo clearly felt his background and gender ideology influenced his current family situation.

One way men in my sample came to accept their caregiving responsibilities was to focus on how their unpaid work benefited their families and by describing how they developed new parenting skills.

\section{Supporting Wives' Careers}

Many of these participants redefined their positions as a way to reconcile their lived experiences with the norms of traditional masculinity. Providing for one's family meant supporting their wives' careers by doing the housework and childcare. These men recognized that their wives' careers might be hurt by having to engage in childcare. They drew on the language related to the motherhood and wage penalty (Budig \& England, 2001) to support their economically subordinate position so that their wives could have successful careers. For example, Eric said The reality of it is, we're in a fortunate position where there is no way I'll ever catch up to my wife and her salary. So the added pressure, the added stress [of us both working], it just doesn't make sense for us, especially with three kids . . . It doesn't bother me if she makes more; it's purely a matter of: Is it worth it, you know? Is it worth getting into a fight and stressing out about who is going to go to the soccer game for the $\$ 30,000$ salary or $\$ 40,000$ salary that might end up going to a daycare or going to babysitters.

Theo described how he supported his wife's career and tried to make their family life less "stressful" by doing unpaid work,

And so one of the things about a stay-at-home parent means that I can take care of all those things in a way that works for me and make sure that when [my wife] is done working we can probably spend that time together. Even her wanting to do work - that's actually her hobby, is doing more planning and work. That's the type of person she is, which is a great fit. But because I'm a stay-at-home parent, I feel like we have the ease of like preparing meals for [my daughter]. I was able to work out all the different prepared foods and things like that; I was able to steam vegetables and puree them and just make things that she would eat, and it was very convenient. I didn't have to worry about transporting things that had to be maintained and changes the bottles and all that kind of stuff, it 
was just like - it's all here, she can wear whatever she wants, I can throw them in the wash, I can do the wash every day, it's not a problem, it's not: coming home from work and now we have to wash this stuff. It's not the pick up and drop off from the daycare. There is so much savings in time.

Deviating from the traditional norms of masculinity and from financial provision did not negatively affect men in my study in the same ways men in previous studies reported (Chesley, 2011; Doucet, 2004; 2009). These stay-at-home fathers did not describe masculine household activities they did in an effort to appear more masculine. They expressed more comfort with their caregiving responsibilities and their secondary economic status than in previous research. This level of comfort was likely related to the economic privilege granted by their class status. These men's wives' high-paying careers granted them comfortable standards of living, which alleviated much of the social burden to economically provide for one's family in order to be "manly."

\section{Developing New Parenting Skills}

Instead of discussing the masculine activities they did with their children as a way to "reinforce their masculinity" (Doucet, 2004, p. 292) when I asked how to describe themselves as fathers, men in my study focused on the nurturing and caregiving skills they developed since becoming stay-at-home fathers. Joel had this to share about how he had grown as a father,

Macho goes a long way in [the south]. And it goes a long way with being a guy from the south, and while I don't know that I ever needed the kids for me to get in touch with my emotional side, just because of what I did for so long, it made things a lot clearer to me, what was important and what wasn't important. While I thought I had a pretty good idea of that already, it doesn't mean shit when you've got these two kids staring at you ... I feel like I've grown leaps and bounds, other than just the waist line.

Kevin compared himself to his own father. He said,

When I first started doing it, I was just like: Jesus Christ take your nap, for God's sakes. And then I started thinking about it thinking, well, okay, but if he just woke up two hours ago he probably doesn't want his nap. So I'm a lot better now about thinking about why he's doing what he's doing. And is he or is he not or is this the right time? It's the patience aspect. I think I've gotten a whole lot better with that [and] I feel like as a father I'm more patient than my dad was.

Some men attributed their feelings to the close contact they had with their children - it allowed for them to have good relationships with their children and they felt good about how they parented. Zach shared his feelings,

Since I spend much more time with them, I think I got better at learning how to read them. And saying: Okay, the reason my daughter is cranky is because she's hungry. Okay, now this time she's really tired or she's just frustrated at this point because she didn't get her way. And learning how 
to react in a way that's appropriate to the situation. . . Between learning how to manage the household, all the job duties that's entailed, and the kind of emotional work that I don't think fathers are necessarily trained for; those are the two biggest things that I had to learn kind of on the job as I went.

One man, Luke, said he felt like a positive role model for other children. He worked on a part-time basis with a fathering group in his town and felt like being a stay-at-home father was an extension of this work. He said,

I think that it not only did it help [my son] to be the dad who is willing to be president of the classroom or at the park or wherever, but it also helps every other kid there too to see a dad involved when you are in the school ... You go to the elementary school and you have a custodian and a maintenance staff and maybe a token gym teacher who were male and that's it that the boys get to see. And so when you have a dad involved and I firmly believe that it's not only helping [my son] out, but it is good influence for all the other kids, provided that dad is a good influence in the first place.

Thus, being a good male role model for young boys means practicing masculinity in ways that incorporates a high level of involvement and non-traditional types of involvement, such as volunteering in a school in ways other than coaching sports teams. This illustrates an interesting deviation from the expectations of traditional masculinity in that men in my sample were engaging in activities in which women historically participated.

One man, Fred, described himself in a way that almost embodied what I call, "evolved masculinity." He was always prepared for any situation - childrelated or otherwise. He said,

In the van I've got extra food, extra water, a potty in the van, that comes in handy a lot. I have a whole toolkit in the van that's come in handy with stuff. It's been helpful, not only to me, but for anybody else that I'm around: "You need a band-aid, you need whatever..." So I think a lot of people are impressed with that. And then also from a guy perspective, I actually have a gun rack in the van. I've got a shotgun I keep in the back and a bunch of tie downs. So I've got the daddy stuff and then I've also got real guy stuff with me. It's a unique deal. And on me, I carry my cell phone, a flashlight, a mini-weatherman that's got tweezers and everything, pony tail holders for my daughter, handkerchief for snotty noses, a pen, a notepad and a mini Sharpie.

He had the "real guy stuff" (hegemonic masculinity) as well as involved father materials (“daddy stuff”) to take care of little children. Fred's quote illustrates how some men practiced masculinity using ideas from traditional masculinity, new masculinity, and involved fatherhood to create "evolved masculinity." He is drawing on hegemonic masculine ideal by having the "real guy stuff" and drawing on new masculinity/involved fatherhood ideal by having his "daddy 
stuff." Although it could be argued that he is describing two opposing categories of items (real guy vs. daddy stuff), the fact that he uses them together, seamlessly, I argue demonstrates an integration of the two types of masculine (traditional and new) ideals into one ideal. In addition, it indicates a mastery over fathering that is akin to how these men may have discussed their professional careers - as proficient masters of their work. The components of these stay-at-home fathers' responses to challenges illustrates a "professionalizing" of their work: developing new parenting "skills" and describing their work as valuable in that it supports their wives' careers. Thus, evolved masculinity is a combination of masculine ideals and allows men to still feel like masters over their domains, even if they are deviating from the norms of traditional masculinity.

\section{Conclusion}

Given some women's gains in the labor force, more men have the option to be stay-at-home parents. However, being a stay-at-home father contradicts being a good-provider, a key component of hegemonic masculinity (Connell, 2005; Ferree, 1991). Hegemonic masculinity places men who are employed fulltime (along with other characteristics) in a dominant position in society (Connell, 1987; 2005). Thus, stay-at-home fathers may be seen as less than "real" men.

My research illustrates the various ways privileged stay-at-home fathers in the United States experience challenges to their masculinity and how they respond to these challenges. Men experience challenges from family members, friends, strangers, and from internalized pressures to live up to traditional masculinity. In all these instances, these men no longer feel appreciated for their previous "masculine" accomplishments (such as athletic achievements, educational attainments, military service). Thus, they experience a degree of emasculation. In response to these challenges, men in my sample draw on stoicism to ignore the challenges, confront others for their negative attitudes about participants' stay-athome status, emphasize their critical role in supporting their wives' careers, and highlight their new parenting skills to demonstrate proficiency in their role.

Men in the United States who are out of the labor force and taking care of children are labeled the "other," the "Not-A" to the employed men's "A," to use Judith Lorber's terminology (1994). In my sample, men recognize that their roles as primary caregivers are incongruent with the ideal of traditional masculinity. Because these men do not embody a key component of traditional masculinity (e.g., breadwinner) and because they exhibit family behaviors that are closely aligned with femininity (e.g., caregiver), they experience a degree of emasculation. However, they also challenge ideals of traditional masculinity by focusing on other activities and skills. In a way, these men are professionalizing fathering by emphasizing the skills they bring to fathering and the activities they do with their children, perhaps in an attempt to align their family work with traditional masculine ideals. Thus, when developing evolved masculinity, they integrate tenants of traditional masculinity.

Both internal dynamics and social context create hegemonic masculinity (Kerfoot \& Knights, 1998; West \& Zimmerman, 1987). It is an "outcome . . . wherein identity and subjectivity are conceived of as always in process" (Kerfoot 
\& Knights, 1998, p.11). Everything we do, as individuals, is scrutinized by others in terms of gender norms; our actions are policed for adherence to gender norms (Connell \& Messerschmidt, 2005). Thus, we try to make our actions fit within the confines of traditional femininity and hegemonic masculinity (Connell, 1992; Lorber, 1994; West \& Zimmerman, 1987). So, too, is it for the men in my study. Through a process of interacting with others and their own ideas about gender, these men construct a new type of masculinity that does not rely on paid employment. But, they do draw on language of traditional and new masculinity, which expects that men will "provide" for their families, and language of involved fatherhood, which expects that men will be responsible for childcare and engaged with family life on a consistent basis. This combining of ideals creates what I term "evolved masculinity." Evolved masculinity entails being fathers/husbands who support wives' professional live and who are committed to a high level of engagement with family life and family work. Evolved masculinity enables men to be engaged in family life in a new way. It signals the continuing evolution of masculinity away from its traditional ideal, at least for men with certain social and economic privileges.

\section{Acknowledgments}

Research related to this paper was previously presented at the winter meeting of Sociologists for Women in Society. This research and article were supported by a Grant-in-Aid and a Summer Research Grant from the College of Arts and Sciences at Quinnipiac University. I am very grateful to the participants for sharing their experiences with me. I thank Alayna Kanata, Sacha Kaufer, Stephanie Araujo and Alexandria Cunningham for research assistance, Rachel Campbell for her helpful comments, and Heather Laube and the anonymous reviewers for their thoughtful suggestions for revision.

\section{References}

Aumann, K., Galinsky, E., \& Matos, K. (2011). The new male mystique: The national study of the changing workforce. New York, NY: Families and Work Institute.

Bogdan, R., \& Biklen, S. K. (1998). Qualitative research of education: An introduction to theory and method, $3^{\text {rd }}$ ed. Boston, MA: Allyn and Bacon.

Budig, M.J., \& England, P. (2001). The wage penalty for motherhood. American Sociological Review, 66, 204-225.

Chesley, N. (2011). Stay-at-home fathers and breadwinning mothers: Gender, couple dynamics, and social change. Gender \& Society, 25, 642-664.

Connell, R.W. (1987). Gender and power: Society, the person and sexual politics.

Stanford, CA: Stanford University Press.

------. (2005). Masculinities. Berkeley, CA: University of California Press.

Connell, R. W., \& Messerschmidt, J.W. (2005). Hegemonic masculinity: Rethinking the concept. Gender \& Society, 19, 829-859.

Cooper, M. (2002). Being the 'go-to guy': Fatherhood, masculinity, and the organization of work in Silicon Valley, in N. Gerstel, D. Clawson, \& R. 
Zussman (Eds.), Families at work (pp. 5-31). Nashville, TN: Vanderbilt University Press.

Doucet, A. (2006). Do men mother?: Fathering, care, and domestic responsibility. Toronto, Canada: University of Toronto Press.

Doucet, A., \& Merla, L. (2007). Stay-at-home fathering: A strategy for balancing work and home in Canadian and Belgian families. Community, Work, and Family, 10, 455-473.

Ferree, M. M. (1991). Beyond separate spheres: Feminism and family research, in A. Booth (Ed.), Contemporary families: Looking forward, looking back (pp. 102-121). Minneapolis, MN: National Council on Family Relations.

Fields, J. (2003). Children's living arrangements and characteristics: March 2002. Retrieved May 19, 2011, from http://www.census.gov/prod/2003pubs/p20-547.pdf.

Government of Canada. (2013). Employment insurance maternity and parental benefits. Retrieved July, 11, from

http://www.servicecanada.gc.ca/eng/ei/types/maternity_parental.shtml\#much.

Jacobs, J. N., \& Kelley, M. L. (2006). Predictors of paternal involvement in childcare with dual-earner families with young children. Fathering: A Journal of Theory, Research, and Practice about Men as Fathers, 4, 2347.

Kerfoot, D., \& Knights, D. (1998). Managing masculinity in contemporary organizational life: A managerial project. Organization, 5, 7-26.

Kramer, K. Z., Kelly, E., \& McCulloch J. (2010). Stay-at-home fathers: Definitions and characteristics based on 40 years of CPS data. Presented at the Population Association of America annual meeting.

Lamb, M. E. (2000). The history of research on father involvement: An overview. Marriage and Family Review, 29, 23-42.

Lorber, J. (1994). Paradoxes of gender. New Haven, CT: Yale University Press.

Marks, L., \& Palkovitz, R. (2004). American fatherhood types: The good, The bad, and the uninterested." Fathering: A Journal of Theory, Research, and Practice about Men as Fathers, 2, 113-129.

Merla, L. (2008). Determinants, costs, and meanings of Belgian stay-at-home fathers: An international comparison. Fathering, 6, 113-133.

Pleck, E. H. and Pleck, J. H. (1997). Fatherhood ideals in the United States: Historical Dimensions, in M.E. Lamb (Ed.), The role of the father in child development ( ${ }^{\text {rd }}$ ed.) (pp. 33-48). Hoboken, N J: Wiley.

Risman, B. J. 1998. Gender vertigo: American families in transition. New Haven, CT: Yale University Press.

Rochlen, A. B., McKelley, R. A., Suizzo, M., \& Scaringi, V. (2008). Predictors of relationship satisfaction, psychological well-being, and life satisfaction among stay-at-home fathers. Psychology of Men \& Masculinity, 9, 17-28.

Rochlen, A. B., Suizzo, M., McKelley, R. A., \& Scaringi, V. (2008). 'I'm just providing for my family': A qualitative study of stay-at-home fathers. Psychology of Men \& Masculinity, 9, 193-206. 
Rochlen, A. B., McKelley, R. A., \& Whittaker, T. A. (2010). Stay-at-home fathers' reasons for entering the role and stigma experiences: A preliminary report. Psychology of Men \& Masculinity, 11, 279-285.

Solomon, C. R. (2014). “'I Feel Like a Rock Star': Fatherhood for Stay-at-Home Fathers." Fathering 12, 1, 52-70.

Strauss, A., \& Corbin, J. (1990). Basics of qualitative research: Grounded theory procedures and techniques. Newbury Park, CA: Sage.

United States Census Bureau. (2013). Facts for features: Father's day June 17, 2013. Retrieved May 9, 2013, from http://www.census.gov/newsroom/releases/archives/facts_for_features_sp ecial_editions/cb13-ff13.html .

Wall, K., Aboim, S. \& Marinho, S. (2007). Fatherhood, family and work in men's lives: Negotiating new and old masculinities. Recherches sociologiques et anthropologiques, 2, 105-122.

West, C., \& Zimmerman, D. H. (1987). Doing gender. Gender \& Society, 1, 125151.

Wisensale, S. K. (2001). Family leave policy: The political economy of work and family in America. Armonk, NY: M.E. Sharpe. 